\title{
THE NAMES OF HAWKS
}

\section{By DR. STUART HOUSTON}

One of the problems that concerns us greatly is the needless and wanton destruction of our beneficial hawks. Our commoner hawks are a great asset to the farmer, as they destroy large numbers of mice and gophers. As one method of educating our younger members to these facts, we try to teach them how to identify the different groups of "Hawks."

First of all, the big, fat, sleepy-looking hawks that perch on a fence pole or telegraph pole, are "gopher hawks" or Buteos. They are beneficial. Secondly, the birds that diet predominantly on smaller birds, and farmers' chickens, are the Accipiters. They are wary, swift moving birds, who spend most of their time in wooded areas, and it is hard to get a good look at them, and I have yet to meet a farmer in this district who has been able to shoot one. As a good safe rule, which will rarely be wrong, I always say, "Never shoot a hawk you can get near enough to shoot."

Peterson, in his "Field Guide to Birds" says that in England the only birds called hawks are the "Accipiters." The colonists who first settled on this continent were not naturalists, so they applied the name Hawk to almost all the day-flying raptores. This has been a great handicap because of the stigma attached to the name "Hawk."

In Yorkton, we have found that the boys can soon learn to recognize the beneficial "Buteos," and name them often at up to a mile away, long before we can tell which species it is. We have stopped calling them "Hawks." We also try to follow Peterson in calling the Marsh Hawk, the Marsh Harrier; the Sparrow Hawk, the Kestrel; the Pigeon Hawk, the Merlin; and the Duck Hawk, the Peregrine. To help with this little project, we have similarly changed the names in the new Field Checking List.

\section{Saw-Whet Owl}

George M. Hruska, Gerald, Sask.

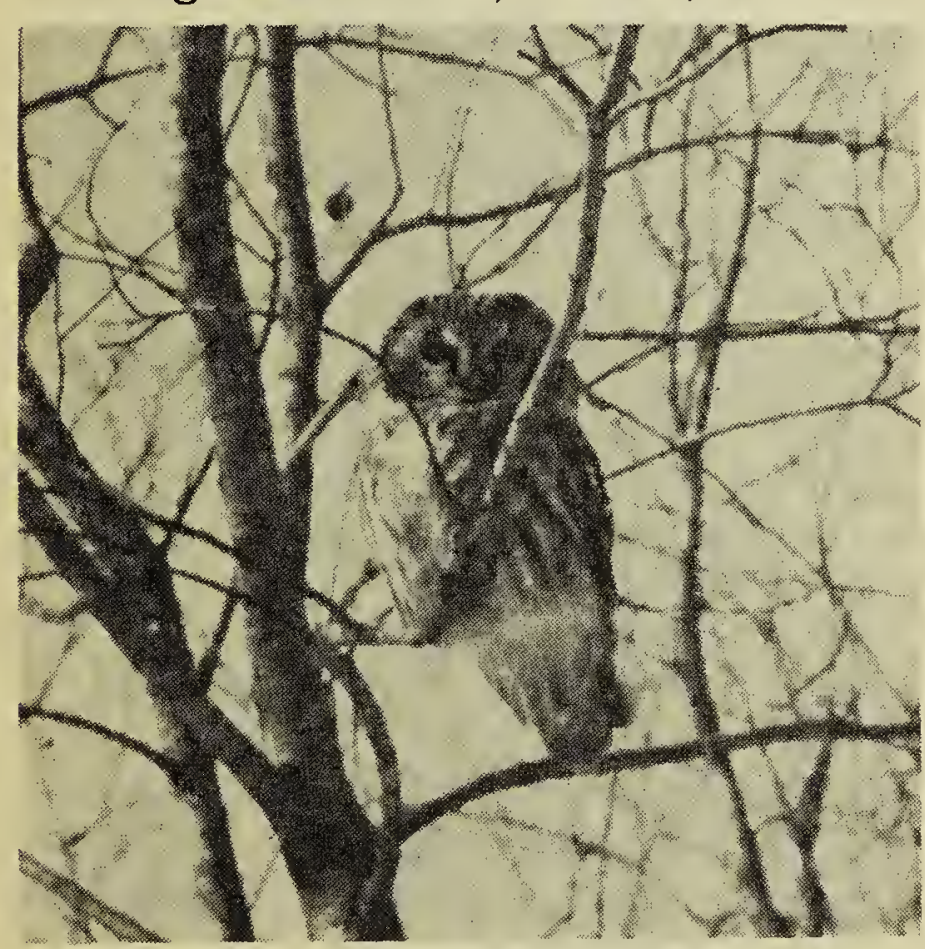

This little Owl is a Saw-whet and it has been around our straw cattle shed for about four winters. It seems to be very tame. I came so close when taking this picture that I could easily have touched it with my hand.

We've had a very good year for hawks at Gerald this spring. I counted twelve in the sky at once within a half mile from me. Also I have seen four Bald Eagles, so far. Probably the reason for their abundance is because of the large number of bush rabbits.

\section{The Return Of The Hawks}

\author{
Joyce Gunn, \\ Spirit Lake, Sask.
}

The week end of April 10th and 11 th was noted in this district for the great number of hawks in evidence. We had noticed a few going over each day but it was not until Saturday that the numbers really increased and then on Sunday the 11th they were really here in full force. In the morning I spotted a large flock circling and after three counts finally decided there were between 55 and 60 in the flock.

In the afternoon, armed with a sketch pad, pencil and binoculars I took up a position on one of the higher sandhills and proceeded to see how many species there were. The most numerous seemed to be the Redtailed, followed closely in num-

(Continued on page 31 ) 


\section{Comservantion or Fise"g}

protection, wildlife can maintain itself, not only to provide us with material benefits but also equally important aesthetic values and benefits.

Now, in summing up this valuable booklet, the fact is stressed that, "Conservation is the concern of everyone," and it has shown the complete interrelationship of all resources, and how civilization is upsetting the balance that existed before civilization took place. While a lot of harm has already been done, we must now look to the future, and realize that it is our duty to repair, conserve, maintain and improve our natural endowment which we hold in trust for future generations.

This obligation is not confined to any given area, or a group of persons, but to everyone, as citizens of the whole world. With world population increasing at the rate of twenty-four million each year, the need for conservation must be apparent to everyone. In other words Conservation is the concern of everyone; it is the concern of farmers, foresters, trappers, commercial fishermen, miners, hunters and anglers. Even business and professional men must realize that there is no form of business, industry or finance which does not owe its prosperity, if not its very existence, to the wealth that springs from the earth-from the farms, the mines, the forests, water, and wildlife.

It is basic that every individual of each generation recognize his obligation to future generations, and to the land on which we live. I am sure that every nature lover and conservationist will find this booklet invaluable and interesting. The address of the Council is as follows: Conservation Council of Ontario, $85 \mathrm{King}$ St., East, Toronto.

The writer of this review, along with others, believes that we need a similar organization here in Saskatchewan, and that members of the Natural History Society should give it serious consideration. Whether the set-up should be inside the Saskatchewan Natural History Society or independently is a matter that should be discussed at length by everyone interested and concerned.

\section{Foot Print In Stone}

\section{Andrew Wautier, Esterhazy, Sask.}

I just read the interesting article by Allan J. Hudson, dealing with artifacts. My neighbor has a stone with a foot print. I have seen the one in the museum at Regina, but this is different. It is much smaller, and perfect as to details. I am sure it is genuine. It was found on a stony hill among countless other stones of glacial deposit. I think it dates beyond the glacial age, and so would like an expert to see it. I am not able to convince the owner to send it in. The owner made a plaster cast of the print and sent it, along with a sample of the stone, to the Smithsonian Institute. Their answer was that the print, although it looks like the real thing, cannot possibly be human, as the stone formation, when in the mud stage, was before the advent of human life.

My idea is that the sample upsets some of their theories, and they are not willing to admit it. (Not a likely action for any scientist.-Ed.)

\section{The Return of the Hawks} (Continued from page 21)

ber by the Rough-legged. But most of the others were also there Marsh, Goshawk and Cooper's and Swainson's. During the afternoon they kept coming over the hills continually moving from East to West. At one time, besides the ones in actual flight low over the hills, there were two huge flocks circling - one to the west and the other to the south-east. The larger one was well spread out and contained 58 birds at various altitudes. The other had 47 in it. It took three countings of each flock to get the number because they were continually circling and at times seemed to be mere dots in the sky.

We have never seen such a congregation of hawks in this district before, and, although most of them have left, we still seem to have a large number around. 